\title{
Effect of omeprazole on the secretion of intrinsic factor, gastric acid and pepsin in man
}

\author{
E KITTANG, E AADLAND, AND H SCHJØNSBY \\ From Medical Department B, Aker University Hospital, Oslo, Norway.
}

SUMmary The effect of an intravenous infusion of omeprazole $(0.35 \mathrm{mg} / \mathrm{kg})$ and placebo on basal and stimulated (pentagastrin $1.0 \mu \mathrm{g} / \mathrm{kg} / \mathrm{h}$ ) secretion of gastric acid, intrinsic factor and pepsin was studied in 10 healthy male subjects. Omeprazole caused a marked inhibition of basal and stimulated acid output. The inhibition of pepsin output was less marked, but also significant. The output of intrinsic factor, however, showed no significant change. The results indicate that acid and intrinsic factor might have different secretory mechanisms within the parietal cell.

Omeprazole (5-methoxy-2(((4-methoxy-3.5dimethyl-2-pyrydinyl)-methyl)sulphinyl)-1Hbenzimidazole), which is the most effective of the substituted benzimidazoles, is a potent inhibitor of acid secretion in isolated parietal cells, ${ }^{1}$ isolated gastric glands, ${ }^{2}$ as both in animals ${ }^{3}$ and in man. ${ }^{4}$ These drugs inhibit gastric acid secretion by a mechanism different from antisecretagogues known so far, and studies have provided evidence that omeprazole inhibits the enzyme $\mathrm{H}^{+} \mathrm{K}^{+}$-ATP-ase, ${ }^{67}$ which is suggested to be the proton pump of the parietal cell. ${ }^{89}$

Intrinsic factor ${ }^{10}$ as well as gastric acid is secreted by the parietal cell. Inhibitors of gastric acid secretion such as histamine $\mathrm{H}_{2}$ receptor antagonists $^{11-13}$ as well as atropine ${ }^{14}$ have been shown to reduce intrinsic factor secretion. Whether or not omeprazole inhibits intrinsic factor secretion is, however, not known.

The present investigation was undertaken to measure the effect of omeprazole on acid and intrinsic factor secretion. The effect of omeprazole on pepsin secretion was also measured, since previous studies have shown different results. ${ }^{15-17}$

\section{Methods}

SUBJECTS

Ten healthy male volunteers (mean age 26 years, range 21-37 years) gave written informed consent to the study. The study was approved by the Ethical

Address for correspondence: Dr E Kittang, Medical Department B, Aker Hospital, Oslo, Norway.

Received for publication 13 July 1984
Committee at Aker University Hospital, Oslo, Norway.

The gastric acid concentration was measured by titration with $0.1 \mathrm{M} \mathrm{NaOH}$ to $\mathrm{pH} 7.4$ using an automatic titrator. (Radiometer, Copenhagen, Denmark).

Aliquots of the gastric juice were depepsinised by adjusting the $\mathrm{pH}$ to 10 with $1 \mathrm{M} \mathrm{NaOH}$. After 30 minutes the $\mathrm{pH}$ was adjusted to 7.0 with $1 \mathrm{M} \mathrm{NaOH}$ and stored at $-20^{\circ} \mathrm{C} .{ }^{18}$

The intrinsic factor concentration was measured by the method of Gottlieb using intrinsic factor antibody from patients with pernicious anaemia. ${ }^{19}$ The concentration of intrinsic factor in the gastric juice was expressed in $\mathrm{U} / \mathrm{ml}$, where 1 unit is the amount of intrinsic factor bound to $1 \mathrm{ng}$ ${ }^{57}$ co-cyanocobalamin. The variation of duplicates in the assay was found to be $1.78 \% \pm 0.22 \%$ (mean variation coefficient $\pm \mathrm{SD}$ ), and the between assay variation coefficient $11.8 \%$. The samples from the omeprazole and the placebo experiments were analysed in the same batch.

Pepsin concentration was measured by the method of Berstad ${ }^{20}$ using human haemoglobin as substrate, and samples with $\mathrm{pH}$ exceeding 6.0 were excluded from the statistical analysis of the pepsin data.

The samples for pepsin and gastric acid determination were kept refrigerated until analysed.

Aliquots containaing $61.3 \mathrm{mg}$ omeprazole dissolved in $6.13 \mathrm{~g}$ polyethylenglycol (MW 400) were stored at $-20^{\circ} \mathrm{C}$ until used. Before use omeprazole was diluted in $6.7 \mathrm{mmol} / 1 \mathrm{NaHCO}_{3}$ to a final concentration of $4 \mathrm{mg} / \mathrm{ml} .6 \cdot 13 \mathrm{~g}$ polyethylenglycol diluted in $6.7 \mathrm{mmol} / 1 \mathrm{NaHCO}_{3}$ was used as placebo. 


\section{PROCEDURE}

The subjects fasted overnight. At 8 am a gastric tube was positioned with its tip in the distal part of the stomach under fluoroscopic control. The subjects swallowed $200 \mathrm{ml}$ of water, and the contents of the stomach were immediately aspirated. Omeprazole $0.35 \mathrm{mg} / \mathrm{kg}$ or placebo was infused intravenously for five minutes in a double blind manner. One hour later an intravenous infusion of pentagastrin (Peptavlon, ICI, Pharmaceuticals Division, Cheshire, UK) at a dose of $1.0 \mu \mathrm{g} / \mathrm{kg} / \mathrm{h}$ was started and continued for 90 minutes. The gastric juice was aspirated by continuous suction, and collected on ice in 15 minute portions. Outputs of intrinsic factor and acid were calculated from measurements carried out in aspirates obtaincd during the 60 minute basal period and the 90 minute period when pentagastrin was infused. The pepsin data were calculated from the last 60 minutes with pentagastrin.

Before and after termination of the experiments, blood and urine samples were taken for routine laboratory tests. (Blood: ESR, Hb, Hct, RBC, WBC, differential count, thrombocytes, ASAT, ALAT, alkaline phosphatase, bilirubin, $\mathrm{Na}^{+}, \mathrm{K}^{+}$, $\mathrm{Cl}^{-}, \mathrm{Ca}^{2+}$, creatinine, bicarbonate. Urine: glucose, protein, haemoglobin and microscopy). Omeprazole was well tolerated as no significant changes were observed in laboratory values. Neither were any side effects because of omeprazole seen or reported by the subjects.

The results were presented as mean values and SEM. A paired Wilcoxon's ranked sum test was used for statistical analyses, and $p$ values $<0.05$ were regarded as significant.

\section{Results}

\section{ACID SECRETION}

Both basal and pentagastrin stimulated gastric acid output was significantly inhibited by omeprazole. (Figure $1 \mathrm{~b}$ ). The inhibition of basal acid output increased subsequently during the whole basal period, indicating that the inhibition recorded was not maximal. The inhibition of stimulated acid output was $74 \cdot 1 \% \pm 5 \cdot 2 \%$ (mean \pm SEM; $p<0 \cdot 01$ ), and was because of a significant inhibition of both $\mathrm{H}^{+}$concentrations (mean inhibition $39.0 \% \pm 9.3 \%$; Figure $1 \mathrm{a}$ ), and volumes of gastric juice (mean inhibition $59 \cdot 1 \% \pm 4 \cdot 6 \%$ ).

INTRINSIC FACTOR SECRETION

Both basal and stimulated concentration of intrinsic factor was higher after omeprazole infusion than after placebo, whereas the output of intrinsic factor did not significantly change (Figure $2 \mathrm{a}$, b; Table).

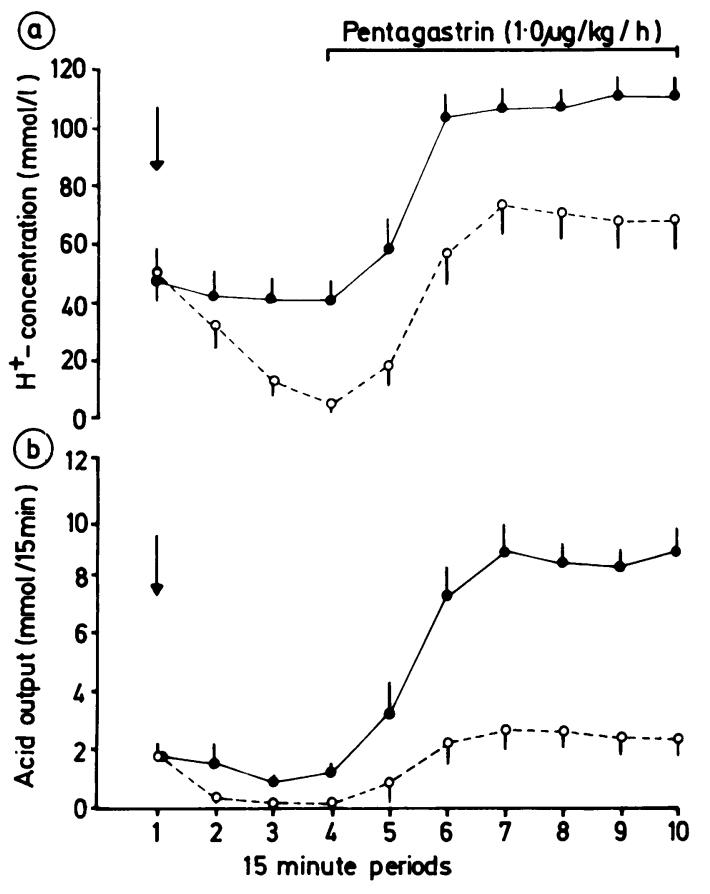

Fig. 1 Effect of iv omeprazole $0.35 \mathrm{mg} / \mathrm{kg}$ on basal and pentagastrin stimulated acid concentration $(a)$, and acid output (b). Arrows indicate when omeprazole or placebo were infused. The results are shows as mean \pm SEM. (○....- omeprazole, @ $\bullet$ placebo).

\section{PEPSIN SECRETION}

In the basal period omeprazole caused a marked rise in $\mathrm{pH}$ in gastric juice that exceeded 6 in several samples. As pepsin is irreversibly degraded at $\mathrm{pH}$ above $6,{ }^{21}$ the pepsin data from the basal period were considered unreliable and was excluded from the statistical analyses. During pentagastrin stimulation mean pepsin output decreased from $125.3 \mathrm{mg} \pm 7.9 \mathrm{mg}$ (placebo) to $79.6 \mathrm{mg} \pm 6.3 \mathrm{mg}$ after omeprazole $(\mathrm{p}<0 \cdot 01)$ whereas the mean pepsin concentration increased from $413 \mathrm{mg} / \mathrm{l} \pm 34 \mathrm{mg} / \mathrm{l}$ (placebo) to $817 \mathrm{mg} / \mathrm{l} \pm 189 \mathrm{mg} / \mathrm{l}$ after omeprazole $(p<0.01$; Figure $3 \mathrm{a}, \mathrm{b})$.

\section{Discussion}

The potent inhibitory effect of omeprazole on acid secretion was confirmed in the present study when stimulating the secretion with a submaximal dose of pentagastrin $(1.0 \mu \mathrm{g} / \mathrm{kg} / \mathrm{h} ;$ Fig $1 \mathrm{a}, \mathrm{b})$. The output of intrinsic factor was unchanged after omeprazole (Table, Fig 2 b). The concentration of intrinsic factor in the gastric juice increased, probably 
Table Basal and pentagastrin $(\mathrm{Pg})$ stimulated intrinsic factor concentration and intrinsic factor output after an intravenous infusion of omeprazole and placebo (Mean $\pm S E M)(n s=$ not significant $)$

\begin{tabular}{llllll}
\hline & \multicolumn{2}{l}{ Intrinsic factor concentration $(U / \mathrm{ml})$} & & \multicolumn{2}{l}{ Cumulative intrinsic factor output } \\
\cline { 2 - 3 } & Basal & & & Basal $(U / 60 \mathrm{~min})$ & $P g(U / 90 \mathrm{~min})$ \\
\hline Omeprazole & $41 \cdot 0 \pm 4 \cdot 1$ & $82 \cdot 4 \pm 18 \cdot 5$ & & $2479 \pm 540$ & $13719 \pm 3172$ \\
Placebo & $28 \cdot 1 \pm 0 \cdot 5$ & $42 \cdot 6 \pm 13 \cdot 5$ & & $3239 \pm 836$ & $16424 \pm 2051$ \\
$\mathrm{p}$ & $<0 \cdot 01$ & $<0 \cdot 01$ & $\mathrm{~ns}$ & $\mathrm{~ns}$ \\
\hline
\end{tabular}

because of reduced volume secretion. Hence, the results show that omeprazole, at a dose causing marked inhibition of acid secretion, has no effect on basal and pentagastrin stimulated intrinsic factor secretion. The effect of maximal doses of omeprazole on intrinsic factor secretion is, however, not known.

As the parietal cell is the site of both acid and intrinsic factor production, ${ }^{10}$ the different effect of omeprazole on intrinsic factor and acid secretion is of interest. It is known that omeprazole interacts with the enzyme $\mathrm{H}^{+} \mathrm{K}^{+}$-ATP-ase, which is located
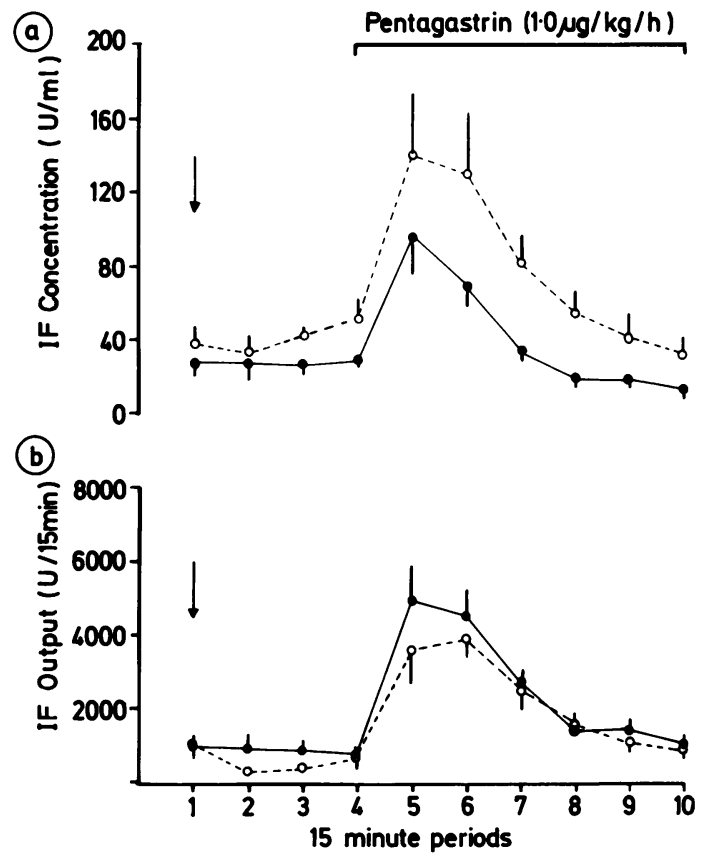

Fig. 2 Effect of iv omeprazole on basal and pentagastrin stimulated intrinsic factor concentration (a) and intrinsic factor output (b). (Symbols as in Fig. 1.) in the secretory membrane of the parietal cell, ${ }^{67}$ and appears as such to be a peripherial step in the secretory mechanism of hydrochloric acid. The different effect of omeprazole on acid and intrinsic factor secretion therefore support the hypothesis that acid and intrinsic factor have separate secretory mechanisms in the parietal cell.

Intrinsic factor is essential for normal absorption of vitamin $B_{12}$. One might therefore expect that omeprazole treatment should be without effect on absorption of vitamin $B_{12}$. Nevertheless it has been proposed that achlorhydria or hypochlorhydria

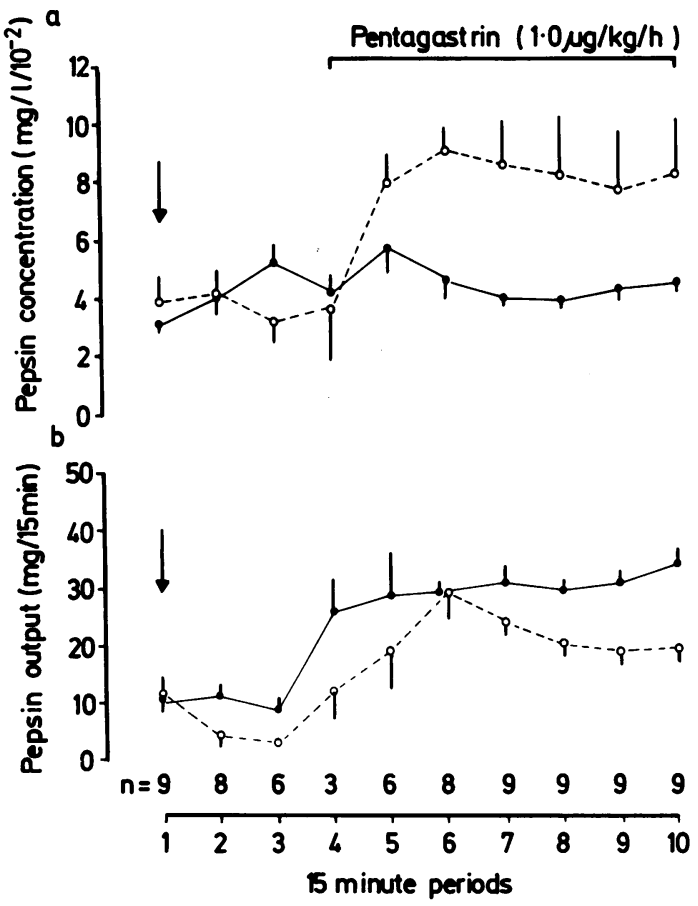

Fig. 3 Effect of iv omeprazole on basal and pentaga;strin stimulated pepsin concentration (a) and output (b). $n=$ number of samples in each period with $\mathrm{pH}<6 \cdot 0$. (Symbols as in Fig. 1.) 
might reduce the absorption of food-bound vitamin $B_{12}$, even in presence of sufficient amounts of intrinsic factor to ensure normal absorption of unbound vitamin $B_{12}{ }^{22}$ It has been shown that treatment with the histamine $\mathrm{H}_{2}$-receptor antagonists cimetidine and ranitidine reduced the absorption of radioactive cyanocobalamin bound to chicken serum, ${ }^{1323}$ but has no effect on the absorption of unbound radioactive cyanocobalamin. ${ }^{23}$ Whether or not omeprazole inhibits the absorption of vitamin $B_{12}$ still remains to be investigated.

The results also show a moderate inhibition of pentagastrin stimulated pepsin output (Fig 3 a,b). The inhibition of pepsin output $(38.2 \% \pm 7 \cdot 0 \%)$ was less marked than the inhibition of acid output $(74 \cdot 1 \% \pm 5 \cdot 2 \% ; \mathrm{p}<0 \cdot 01)$. During the pentagastrin stimulation the pepsin concentration markedly increased, probably as an effect of reduced volume secretion. The present results are in agreement with those reported in man by Wilson et al. ${ }^{17}$

The mechanism by which omeprazole inhibits pepsin secretion is unknown. Fryklund $e a^{16}$ found that omeprazole did not inhibit pepsinogen released in isolated zymogen cells from rabbit mucosa, whereas the formation of acid in isolated parietal cells was strongly inhibited. The inhibition of pepsin secretion can therefore not be explained by direct omeprazole interaction with the pepsin producing cells. It might be speculated whether the inhibition of pepsin secretion could be an effect secondary to the inhibition of acid secretion, a theory supported by findings that topical application of hydrochloric acid stimulates the secretion of pepsin in vitro ${ }^{24}$ as well as in healthy man. ${ }^{25}$

We wish to thank Dr A Berstad for kindly performing the pepsin measurements. The study was supported by AB Hässle, Mølndal, Sweden.

\section{References}

1 Sewing K-Fr, Harms P, Schulz G, Hanneman H. Effect of substituted benzimidazoles on acid secretion in isolated and enriched guinea pig parietal cells. Gut 1983; 24: 557-60.

2 Fellinius E, Elander B, Wallmark B, Helander HF, Berglindh $\mathrm{T}$. Inhibition of acid secretion in isolated gastric glands by substituted benzimidazoles. Am J Physiol 1982; 243: G505-10.

3 Larsson $\mathrm{H}$, Carlsson E, Junggren $\mathrm{U}$ et al. Inhibition of gastric acid secretion by omeprazole in dog and rat. Gastroenterology 1982; 83: 900-7.
4 Lind T, Cederberg Ch, Ekenved G, Haglund U, Olbe L. Effect of omeprazole - a gastric proton pump inhibitor - on pentagastrin stimulated acid secretion in man. Gut 1983; 24: 270-6.

5 Olbe L, Haglund U, Leth R et al. Effects of substituted benzimidazole (H 149/94) on gastric acid secretion in humans. Gastroenterology 1982; 83: 193-8.

6 Fellenius E, Berglindh T, Sachs G et al. Substituted benzimidazoles inhibit gastric acid secretion by blocking $\left(\mathrm{H}^{+} \mathrm{K}^{+}\right)$ATP-ase. Nature 1981; 290: 159-61.

7 Wallmark B, Sachs G, Mårdh S, Fellenius E. Inhibition of gastric $\left(\mathrm{H}^{+} \mathrm{K}^{+}\right)$ATP-ase by the substituted benzimidazole, picoprazole. Biochim Biophys Acta 1983; 728: 31-8.

8 Saccomani G, Helander HF, Crago S, Chang HH, Dailey DW, Sachs G. Characterization of gastric mucosal membranes. J Cell Biol 1979; 83: 271-83.

9 Sachs G, Chang HH, Rabon E, Schackman R, Lewin $M$, Saccomani G. A nonelectrogenic $\mathrm{H}^{+}$pump in plasma membranes of hog stomach. J Biol Chem 1976; 251: 7690-8.

10 Hoedemaker PJ, Abels J, Wachters JJ, Arends A, Nieweg HO. Investigation about the site of production of Castle's gastric intrinsic factor. Lab Invest 1964; 13: 1394-9.

11 Sharp PC, Mills JG, Horton MA, Hunt RH, Vincent $\mathrm{SH}$, Milton-Thompson GJ. Histamin $\mathrm{H}_{2}$-receptors and IF secretion. Scand J Gastroenterol 1980; 15: 377-84.

12 Fielding LP, Chalmers DM, Chanarin I, Levi AJ. Inhibition of intrinsic factor secretion by cimetidine. $\mathrm{Br}$ Med J 1978; 1: 818-9.

13 Bêlaïche J, Zittoun J, Marquet J, Nurit Y, Yvart J. Effect of ranitidine on intrinsic factor secretion and cobalamin absorption. Gastroenterol Clin Biol 1983; 7: 381-4.

14 Vatn MH, Semb LS, Schrumpf E. The effect of atropine and vagotomy on the secretion of gastric intrinsic factor (IF) in man. Scand J Gastroenterol 1975; 10: $59-64$.

15 Fimmel CJ, Blum AL. Dissociated response of acid and pepsin secretion to omeprazole (H 168/68), a substituted benzimidazole. [Abstract] Gastroenterology 1983; 84: 1152.

16 Fryklund J, Wallmark B, Larsson $H$. Effect of omeprazole on gastric secretion in $\mathrm{H}^{+} \mathrm{K}^{+}-\mathrm{ATP}$-ase and in pepsinogen-rich cell fractions from rabbit gastric mucosa. Biochem Pharmacol 1984; 33: 273-80.

17 Wilson JA, Boyd EJS, Wormsley KG. Effect of omeprazole on pentagastrin stimulated and overnight gastric acid and pepsin. [Abstract] Gastroenterology 1983; 84: 1352.

18 Gräsbeck R. Physiology and pathology of vitamin $B_{12}$ absorption, distribution and excretion. Adv Clin Chem 1960; 2: 299-366.

19 Gottlieb Ch. Rapid charcoal assay for intrinsic factor, gastric juice unsaturated $B_{12}$ binding capacity, antibody to IF and serum unsaturated $B_{12}$ binding capacity. Blood 1963; 25: 875-84.

20 Berstad A. A modified hemoglobin substrate method for the estimation of pepsin in gastric juice. Scand $J$ Gastroenterol 1970; 5: 343-8.

21 Berstad A. Inactivation of human gastric pepsin by 
duoednal juice. Scand J Gastroenterol 1971; 6: 241-4.

22 Doscherholmen A, Swaim WR. Impaired assimilation of egg ${ }^{57} \mathrm{Co}$ vitamin $B_{12}$ in patients with hypochlorhydria and achlorhydria and after gastric resection. Gastroenterology 1973; 64: 913-9.

23 Salom IL, Silvis SE, Doscherholmen A. Effect of cimetidine on the absorption of vitamin $\mathrm{B}_{12}$. Scand $J$
Gastroenterol 1982; 17: 129-31.

24 Kapadia CR, Donaldson RM. Macromolecular secretion by isolated gastric mucosa. Gastroenterology 1978; 74: 535-9.

25 Bynum TE, Johnson LR. Stimulation of human pepsin output by topical hydrochloric acid. Am J Dig Dis 1975; 20: $607-12$. 